\title{
A Reliable Regeneration Method in Genome-Editable Bell Pepper 'Dempsey'
}

\author{
Kang-Hee Won ${ }^{1,+}$, Sung-il Park ${ }^{2,+}$, Jisun Choi ${ }^{1}$, Hyun Hee Kim ${ }^{3}$, Byoung-Cheorl Kang ${ }^{4}$ and Hyeran Kim ${ }^{1,2, *}$ \\ 1 Department of Biological Sciences, Kangwon National University, Chuncheon 24341, Korea; \\ wkh837265@kangwon.ac.kr (K.-H.W.); mujuk34@kangwon.ac.kr (J.C.) \\ 2 Department of BIT Medical Convergence, Kangwon National University, Chuncheon 24341, Korea; \\ stonebridge0@kangwon.ac.kr \\ 3 Department of Chemistry \& Life Science, BioScience Research Institute, Sahmyook University, \\ Seoul 01795, Korea; kimhh@syu.ac.kr \\ 4 Department of Horticulture, Seoul National University, Seoul 08826, Korea; bk54@snu.ac.kr \\ * Correspondence: ranny@kangwon.ac.kr \\ + These authors contributed equally.
}

check for updates

Citation: Won, K.-H.; Park, S.-i.; Choi, J.; Kim, H.H.; Kang, B.-C.; Kim, H. A Reliable Regeneration Method in Genome-Editable Bell Pepper 'Dempsey'. Horticulturae 2021, 7, 317. https://doi.org/10.3390/

horticulturae7090317

Academic Editor: Juan Capel

Received: 15 July 2021

Accepted: 14 September 2021

Published: 16 September 2021

Publisher's Note: MDPI stays neutral with regard to jurisdictional claims in published maps and institutional affiliations.

Copyright: (c) 2021 by the authors. Licensee MDPI, Basel, Switzerland. This article is an open access article distributed under the terms and conditions of the Creative Commons Attribution (CC BY) license (https:// creativecommons.org/licenses/by/ $4.0 /)$.

\begin{abstract}
A reliable regeneration technique is critical for the improvement of pepper traits in the genome editing era. Recently, we reported that peppers were successfully and specifically edited using CRISPR tools, CRISPR/Cas9 and CRISPR/Cas12a (LbCpf1). Although genome-editing tools can be applied to modify peppers at the cellular level, feasible pepper regeneration techniques have not been developed. Therefore, we studied a pepper regeneration protocol for Capsicum annuиm $\mathrm{L}$. 'Dempsey', a bell pepper species that has been proven to be genome-editable. Three explant types were used in this study, including the first leaves, cotyledons and hypocotyls of pepper seedlings. The shoot buds of the tested explants were produced using $8 \mathrm{mg} / \mathrm{L}$ 6-benzylaminopurine (BAP)and $6 \mathrm{mg} / \mathrm{L}$ indole-3-acetic acid (IAA)-containing shoot induction medium (SIM). The first leaves of the 'Dempsey' seedlings showed an average shooting rate of $69.8 \%$, whereas the hypocotyls and cotyledons had approximately $25.5 \%$ and $19.5 \%$ shooting rates, respectively. The regenerated 'Dempsey' plants exhibited no alterations in fruit and fertile seed phenotypes. Furthermore, the parent 'Dempsey' and progenies of the regenerants were cytogenetically stable with the same chromosome numbers $(2 n=24)$. Therefore, this regeneration protocol enables the precise molecular breeding of 'Dempsey' peppers when coupled with CRISPR tools.
\end{abstract}

Keywords: bell pepper regeneration; Capsicum annuum 'Dempsey'; explant types; organogenesis; cytogenetic analysis; pepper breeding

\section{Introduction}

Capsicum is a significant genus of vegetables that provides a good source of antioxidants, vitamin C and pungency. Today, there are five domesticated Capsicum species, Capsicum annuum, C. baccatum, C. chinense, C. frutescens and C. pubescens [1]. Traditional breeding programs have focused on the $C$. annuum to select suitable varieties with good taste and nutrition, better yield and disease resistance [1]. In 2014, pepper genomes were sequenced and standardised as the reference genome to improve agronomic traits in pepper breeding [2,3]. Genome-to-Phenome-based studies and marker-assisted selection have helped define the loci of agronomical characteristics and have become a popular platform for current molecular breeding [4].

Peppers are classified as hot peppers and bell peppers based on the pungency and fruit shape. Bell peppers are bell-shaped and have relatively low spiciness because of the deficiency of capsaicinoids [5]. 'Dempsey' is a sweet pepper that originates from a three-way cross between the 'PI163192' , 'PI264281' and 'Jupiter' cultivars to employ virusand bacterial spot-resistant traits and is classified closely with 'Jupiter' based on single 
position polymorphism (SPP) markers [6,7]. Therefore, 'Dempsey' is an excellent genetic resource with multiple disease resistance, a non-functional pun1 allele as a standard of non-pungency, and whole genomic information [8,9].

In the post-genomic era, several plant scientists including our group have effectively implemented clustered regularly interspaced short palindromic repeats (CRISPR)-CRISPRassociated protein (Cas) (i.e., CRISPR/Cas) technology to engineer genetic resources for crop improvement [10-12]. In fact, several crops including vegetables and fruits have been enhanced using CRISPR tools $[13,14]$. To produce the desired cultivars, we require a competent regeneration protocol for the target crop in addition to the available gene-editing tools. Among the Solanaceae family, tobacco and tomato were first genetically engineered by T-DNA-harbouring Agrobacterium-mediated transformation, and readily applied with regeneration protocols $[15,16]$. Potatoes and eggplants were subsequently engineered by Agrobacterium-mediated transformation coupled with tissue culture $[17,18]$.

However, few successful genetic transformations and regeneration methods have been reported in pepper cultivars over the last two decades [19-23]. 'Pusa jwala', an Indian hot pepper, has been characterised as an optimal cultivar for genetic engineering [22,24-26]. 'California Wonder', a bell pepper, was successfully regenerated from protoplasts in 1997 [27]. Although bell pepper is a well-known recalcitrant species in Agrobacteriummediated genetic engineering, several bell pepper studies have been performed to enhance organogenesis with distinct hormonal compositions in various cultivars [28-30]. Recently, we reported that peppers, including 'Dempsey', are successfully and specifically edited using CRISPR tools, CRISPR/Cas9 and CRISPR/Cas12a (LbCpf1) [31]. Although genomeediting tools can be applied to the recalcitrant peppers at the cellular level [31,32], feasible pepper regeneration has not been achieved yet. Here, we studied tissue culture techniques for Capsicum annuum L. 'Dempsey', a genome-editable bell pepper.

\section{Materials and Methods}

\subsection{Plant Material and Pepper Sowing}

The Vegetable Breeding Research Center (VBRC) in the Republic of Korea provided C. annuum L. 'Dempsey'. Pepper seeds were thoroughly sterilised with $2 \%$ commercial bleach and $0.1 \%$ Tween-20 for $20 \mathrm{~min}$ and washed three times with distilled water for $10 \mathrm{~min}$ each time. The surface-sterilised seeds were germinated on a medium composed of Murashige \& Skoog (MS) medium including vitamins (M0222, Duchefa Biochemie, Haarlem, The Netherlands), MES monohydrate (M1053, Duchefa Biochemie, Haarlem, The Netherlands), $2 \%$ sucrose and 0.8\% phytoagar (P1003, Duchefa Biochemie, Haarlem, The Netherlands), adjusted to $\mathrm{pH}$ 5.8. The sowed plates were incubated at $25{ }^{\circ} \mathrm{C}$ in the dark for a week. The germinated pepper seedlings were grown at $25 \pm 2{ }^{\circ} \mathrm{C}$, a photosynthetic photon flux (PPF) of $135 \mu \mathrm{mol} \cdot \mathrm{m}^{-2} \cdot \mathrm{s}^{-1}$ with a $16 / 8 \mathrm{~h}$ light photoperiod and $60 \%$ relative humidity in a growth chamber for $2-3$ weeks.

\subsection{Shooting and Shoot Elongation}

For explant preparation, first leaves, cotyledons and hypocotyls from 3-4-week-old seedlings were excised into 1-cm-long pieces. The diced 8-16 explants were placed with the adaxial surface upward on a shoot induction medium (SIM), composed of MS salts with MES buffer (M0254, Duchefa Biochemie, Haarlem, The Netherlands), Gamborg B5 vitamin mixture (G0415, Duchefa Biochemie, Haarlem, The Netherlands), 2\% sucrose, 8 mg/L 6Benzylaminopurine, BAP (B0904, Duchefa Biochemie, Haarlem, The Netherlands), 6 mg/L Indole-3-acetic acid, IAA (I5148, Sigma-Aldrich, St. Louis, MI, USA), adjusted to $\mathrm{pH}$ of 5.8 and solidified with $0.8 \%$ agar A (AR3002, Biosesang, Seongnam, Korea). The SIM cultures were maintained at $25 \pm 2{ }^{\circ} \mathrm{C}$ and $60 \%$ relative humidity under a $16 / 8 \mathrm{~h}$ light photoperiod in a growth chamber for 3-4 weeks. Emerged shoot buds from explants were cut and placed on an elongation medium (SEM), composed of MS salts with MES buffer, Gamborg $\mathrm{B}_{5}$ vitamin mixture, $2 \%$ sucrose, $2 \mathrm{mg} / \mathrm{L}$ Zeatin riboside (MB-Z5911, MB cell, Seoul, Korea), $2 \mathrm{mg} / \mathrm{L}$ gibberellic acid, GA 3 (G7645, Sigma-Aldrich, St. Louis, USA), adjusted to pH 5.8 
and solidified alternatively with either $0.4 \%$ gelrite (G1101, Duchefa Biochemie, Haarlem, The Netherlands) or $0.8 \%$ agar A in a plant culture dish $(10 \mathrm{~cm}$ diameter, $4 \mathrm{~cm}$ height). Shoot elongation was maintained in SEM solidified with gelrite for five days and subsequently in agar A for nine days as a subculture. The oxidised brown leaves and callus were repeatedly removed, and multiple shoots were separated from the three subcultures. Shooting rate $(\%)$ $=$ numbers of explant exhibiting shoot buds/total number of the indicated explant $\times 100$.

\subsection{Rooting and Acclimation}

Shoots $(>1.5 \mathrm{~cm})$ were transferred to a culture bottle containing a rooting medium (RIM), composed of MS salts including MES, Gamborg B5 vitamin mixture, $0.1 \mathrm{mg} / \mathrm{L}$ $\alpha$-Naphthalene acetic acid, NAA (N0903, Duchefa Biochemie, Haarlem, The Netherlands), adjusted to $\mathrm{pH} 5.8$ and solidified with agar A. The transferred shoots were sub-cultured every two weeks until they showed a primary root. An emerging root was observed after approximately three to four weeks. Regenerated peppers (R0) with a $>3 \mathrm{~cm}$ root length were transplanted into a soil pot $(9 \mathrm{~cm}$ diameter, $9 \mathrm{~cm}$ height) and kept in full moisture with a transparent plastic lid for two weeks. Successfully acclimated plants were transferred to larger pots ( $15 \mathrm{~cm}$ diameter, $13 \mathrm{~cm}$ height). The 'Dempsey' regenerants R0 were grown at $25 \pm 2{ }^{\circ} \mathrm{C}$ and $60 \%$ relative humidity under a $16 / 8 \mathrm{~h}$ light photoperiod in a growth chamber, and eventually mature, red fruit were harvested. Rooting rate $(\%)=$ number of explants with roots/ total number of explants $\times 100$. Seven R0 regenerants and their ten mature peppers and 159 seeds were collected. The eleven progenies from R0 line \#4 were used for R1 phenotype analyses.

\subsection{Cytogenetic Analysis}

For chromosome preparation from the 'Dempsey'cultivar (Capsicum annuum L.; $2 \mathrm{n}=24$ ) [33], we used fresh root tips of 5-week-old plants from twelve 'Dempsey' controls and eleven R1 regenerants. The excised healthy root tips were pretreated with $2 \mathrm{mM}$ 8-hydroxyquinoline for $5 \mathrm{~h}$ at $18{ }^{\circ} \mathrm{C}$, washed three times and fixed with freshly prepared 3:1 fixing solution, 3:1 (volume) ethanol: acetic acid for $16 \mathrm{~h}$. The fixed root tips were washed three times with $70 \%$ ethanol. Six to seven root tips were digested in $50 \mu \mathrm{L}$ of enzyme solution comprising $2 \%$ cellulose, $1 \%$ pectolyase and $10 \mathrm{mM}$ citric acid/sodium citrate for $90 \mathrm{~min}$ at $37^{\circ} \mathrm{C}$. The digested root tips were washed with a 3:1 fixing solution and rinsed with 9:1 $(v / v)$ acetic acid: ethanol. The roots were mounted in $40 \mu \mathrm{L}$ of the 9:1 acetic acid: ethanol solution onto pre-cleaned slides, and placed in a pre-warmed humid chamber, and then dried at $37^{\circ} \mathrm{C}$. The prepared root slides were treated with $2 \%$ formaldehyde, and washed with absolute ethanol, and dried at $37^{\circ} \mathrm{C}$. The prepared 'Dempsey' roots were stained with 1\% 4',6-diamidino-2-phenylindole dihydrochloride (DAPI) to observe the number of chromosomes using a confocal microscope (Nikon, Tokyo, Japan) from National Research Facilities \& Equipment Center.

For fluorescence in situ hybridisation (FISH), we used slides in which chromosomes were confirmed through DAPI staining. Briefly, the hybridisation mixture contained 50\% formamide, $10 \%$ dextran sulphate, $2 \times$ saline-sodium citrate buffer (SSC), $50 \mathrm{ng} / \mu \mathrm{L}$ per DNA probe and nuclease-free water [34-36]. The $40 \mu \mathrm{L}$ hybridisation mixture was pipetted onto each slide. The chromosomes were denatured at $80{ }^{\circ} \mathrm{C}$ for $5 \mathrm{~min}$ and incubated overnight in a humidity chamber at $37^{\circ} \mathrm{C}$. The following washing steps were performed: $2 \times \mathrm{SSC}$ at RT for $10 \mathrm{~min}, 0.1 \times \mathrm{SSC}$ at $42{ }^{\circ} \mathrm{C}$ for $25 \mathrm{~min}$ and $2 \times \mathrm{SSC}$ at RT for $5 \mathrm{~min}$ on shaker; this was followed by dehydration using a graded series of ethanol solutions: $70 \%$, $90 \%$ and $100 \%$, at RT for 3 min on shaker. The slides were dried and counterstained with $1 \mu \mathrm{g} / \mathrm{mL}$ DAPI in Vectashield (H-1200, Vector Laboratories, Burlingame, CA, USA) and observed under an Olympus BX53 fluorescence microscope (Olympus Corporation, Tokyo, Japan). The captured images were processed using Cytovision ver. 7.2 (Leica Microsystems, Wetzlar, Germany). 


\subsection{Statistical Analysis}

Scatter plots showing the mean and standard deviation were generated using the GraphPad Prism software (GraphPad Prism 8.0, GraphPad Inc., San Diego, CA, USA). The experimental data were statistically analysed using one-way ANOVA coupled with Tukey's HSD test. $p$ values of $<0.05\left(^{*}\right)$ and $<0.01\left(^{* *}\right)$ were considered statistically significant, and non-significant differences were labelled "ns".

\section{Results}

\subsection{Regeneration Procedures of Bell Pepper 'Dempsey'}

Based on the previous reports of various pepper genotypes [28,37-39], we successfully obtained regenerants using conditions of shooting, rooting and regeneration procedures summarised in Table 1. The entire regeneration procedure and images are shown in Figure 1.

Table 1. Summary of media composition and duration of regeneration procedures in Capsicum anпиит L. 'Dempsey'.

\begin{tabular}{|c|c|c|c|c|c|}
\hline Media Name & Phytohormone & Solidifying Agent & & Duration & \\
\hline $\begin{array}{l}\text { Shoot Induction } \\
\text { Medium (SIM) }\end{array}$ & $\begin{array}{l}8 \mathrm{mg} / \mathrm{L} \text { BAP, } \\
6 \mathrm{mg} / \mathrm{L} \text { IAA }\end{array}$ & $0.8 \%$ agar $\mathrm{A}$ & & 4 weeks & \\
\hline \multirow{2}{*}{$\begin{array}{l}\text { Shoot Elongation } \\
\text { Medium (SEM), } \\
3 \text { times subcultures }\end{array}$} & \multirow{2}{*}{$\begin{array}{c}2 \mathrm{mg} / \mathrm{L} \text { Zeatin, } \\
2 \mathrm{mg} / \mathrm{L} \mathrm{GA}_{3}\end{array}$} & $0.4 \%$ gelrite & 5 days & & \multirow{2}{*}{6 weeks } \\
\hline & & $0.8 \%$ agar $\mathrm{A}$ & 9 days & & \\
\hline $\begin{array}{l}\text { Root Inducing } \\
\text { Medium (RIM) }\end{array}$ & $0.1 \mathrm{mg} / \mathrm{L}$ NAA & $0.8 \%$ agar $\mathrm{A}$ & & 3-4 weeks & \\
\hline
\end{tabular}

A

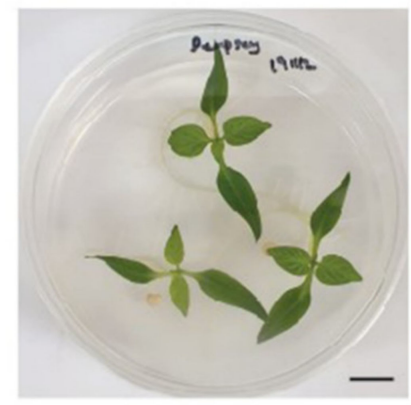

E

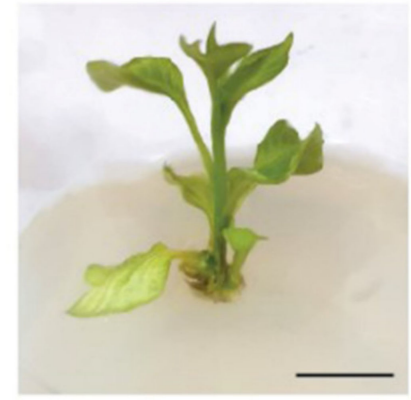

B

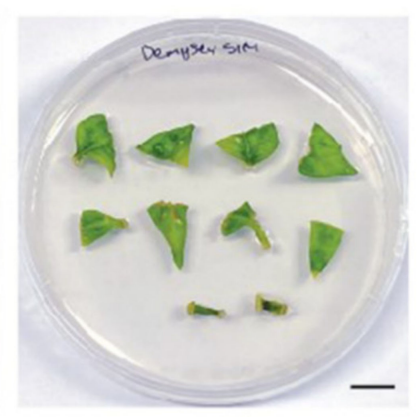

$\mathbf{F}$

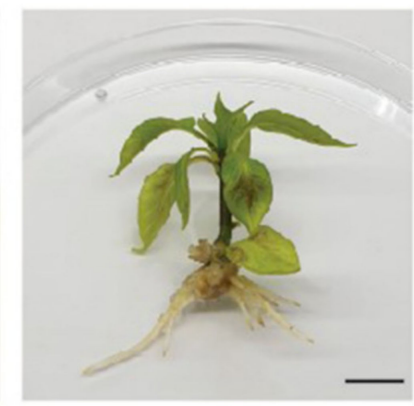

C

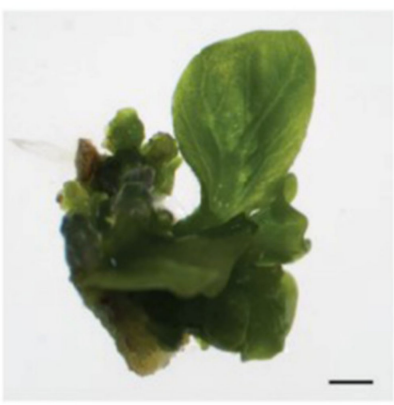

G

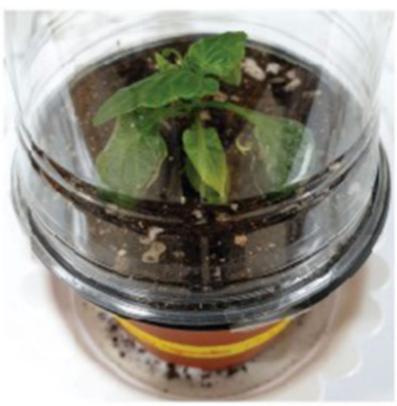

D

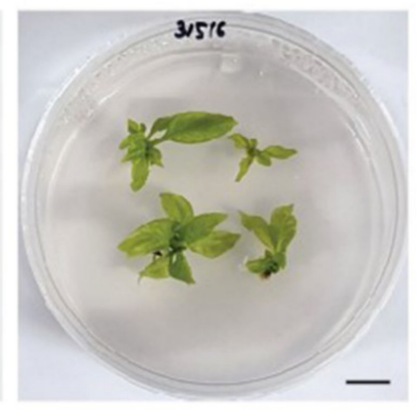

H

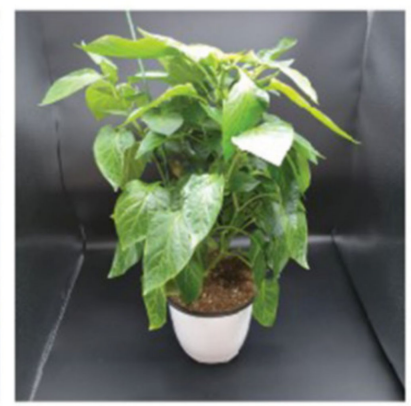

Figure 1. Whole plant regeneration procedure of bell pepper, 'Dempsey'. (A) 3-4-week-old 'Dempsey' bell peppers were used for regeneration. (B) Three types of explants incubated on shoot induction medium (SIM). (C) Magnified image of shoot buds fully grown on SIM for 1 month, scale bar $=1 \mathrm{~mm}$. (D) Elongated shoot buds on shoot elongation medium for 6 weeks. (E) A grown shoot on root induction medium (RIM). (F) Regenerated 'Dempsey' with protruded roots before soil-transplanting, scale bars $(\mathbf{A}-\mathbf{E}$, except $\mathbf{C})=1 \mathrm{~cm}$. $(\mathbf{G})$ Acclimation of peppers with a transparent plastic lid for two weeks after soil-transplanting, $9 \mathrm{~cm}$ diameter of pot. (H) Fully-grown 'Dempsey' regenerant, $15 \mathrm{~cm}$ diameter of pot. 
Three types of explants were used in this study, including the first leaves, cotyledons and hypocotyls of 3-4-week-old 'Dempsey' seedlings (Figure 1A). The $1 \mathrm{~cm}$ excised explants were placed with the adaxial surface upward on shoot induction media (SIM) to obtain emerging shoot buds (Figure 1B and Table 1). Shoot buds were observed at both sides of a petiole and a diced leaf blade of the first leaves, cotyledons and hypocotyls. In a previous study, we reported that proliferative calluses of 'Dempsey' were induced from diced leaf blades at $2 \mathrm{mg} / \mathrm{L}$ of BAP [37]. Bell pepper cultivars in Bangladesh showed the highest shooting rate in 6 to $8 \mathrm{mg} / \mathrm{L} \mathrm{BAP} \mathrm{[38,39].} \mathrm{Considering} \mathrm{previous} \mathrm{studies,} 8 \mathrm{mg} / \mathrm{L}$ of BAP and $6 \mathrm{mg} / \mathrm{L}$ of IAA were incorporated into the growth media for shoot induction. The properly grown shoot buds were observed within 4 weeks on SIM (Figure 1C and Table 1). The successfully regenerated shoots were transferred and grown on shoot elongation medium (SEM) for 6 weeks with a biweekly subculture (Figure 1D and Table 1). Both $2 \mathrm{mg} / \mathrm{L}$ Zeatin and $2 \mathrm{mg} / \mathrm{L} \mathrm{GA}_{3}$ were required for the shoot elongation step. We used two types of solidifying agents, gelrite and agar $\mathrm{A}$, to accelerate shoot growth and avoid vitrification in the SEM. Differentiated multi-shoots were often obtained during shoot elongation. Therefore, we separated the multi-shoots during a biweekly subculture and maintained independent shoots on the SEM. After 6 weeks of SEM, the fully grown shoots with expended leaves were transferred to root induction medium (RIM) including $0.1 \mathrm{mg} / \mathrm{L}$ NAA promoting root formation (Figure 1E and Table 1). When the protruding primary root of the transferred shoots successfully appeared on RIM after 3-4 weeks, it was ready for transplanting to soil pot (Figure 1F). When the regenerated 'Dempsey' was acclimated in a soil pot ( $9 \mathrm{~cm}$ diameter), the critical issue was maintaining the humidity with a transparent plastic lid and avoiding fungal contaminations (Figure 1G). The successfully acclimated regenerants were further grown in a bigger soil pot (15 cm diameter) to produce pepper fruits (Figure 1H). Therefore, 'Dempsey' organogenesis took approximately 4 months to have a shoot-root tissue as a regenerant (R0), and further 5 to 6 month to harvest mature pepper fruits from the regenerant (R0). These results suggested that the established conditions were suitable for 'Dempsey' regeneration.

\subsection{Comparison of Organogenesis Efficiencies among the Three Explant Types}

Previously, pepper hypocotyls and cotyledons were the explant types mainly used for tissue culture [40]. Pepper true leaves are sometimes used for transient expression assays [23]. To examine the optimal explant type, we evaluated three tissues: first leaves, cotyledons and hypocotyls of 3-4-week-old 'Dempsey' seedlings (Table S1). We performed shoot induction experiments on three tissues in SIM and analysed their shooting rates. Unexpectedly, the first leaves showed various shooting rates ranging from $14.6 \%$ to $100 \%$ and the highest shooting rate of $69.8 \%$ was a mean from eight biological replicates in three tissues; hypocotyls ranged from $0 \%$ to $60 \%$ with a mean of $25.5 \%$ from four biological replicates; cotyledons ranged from $0 \%$ to $50 \%$ with a mean of $19.5 \%$ from eight biological replicates in the SIM (Figure 2A and Table S1). All emerging shoot buds from the three explant types were observed at the edge of the excised tissues in the SIM (Figure 2B). We compared the rooting rates of the three explant types (Figure 2C and Table S1). The first leaves showed various rooting rates ranging from $7.1 \%$ to $25 \%$ and the highest rooting rate was a mean of $13.4 \%$ from seven biological replicates among three tissues. Hypocotyls ranged from $0 \%$ to $10 \%$, with a mean of $3.3 \%$ from three biological replicates. Cotyledons ranged from $0 \%$ to $5 \%$, at a mean of $1.6 \%$ from seven biological replicates in the RIM (Figure 2C and Table S1). The protruding roots were observed as several primary roots during the RIM cultivation (Figure 2D). Therefore, the comparative data suggest that the first leaves are the most optimal explant type for 'Dempsey' regeneration. 
A

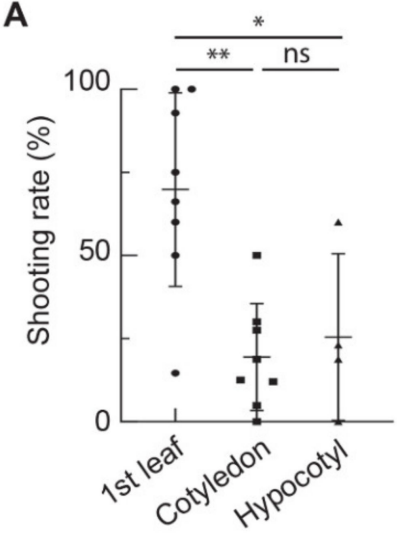

C

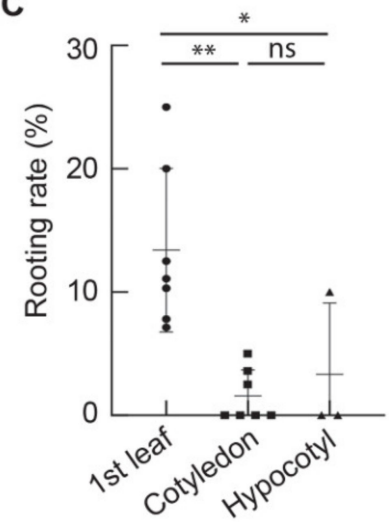

B

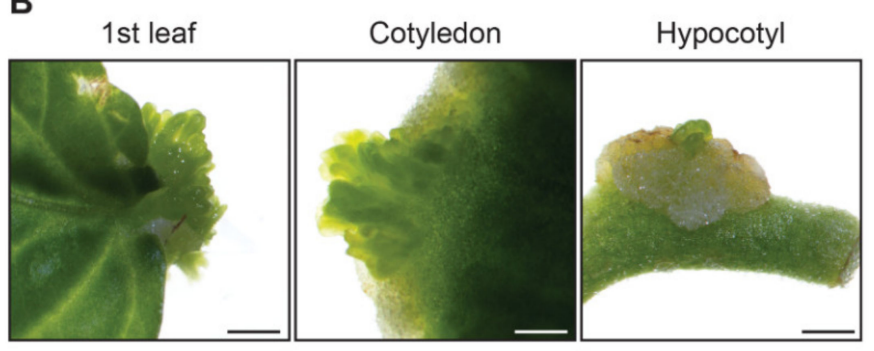

D

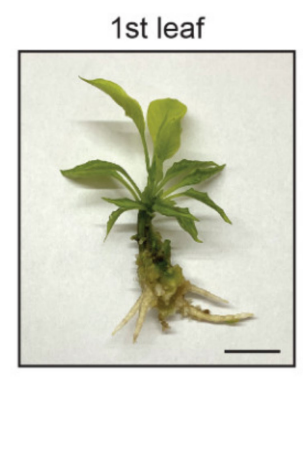

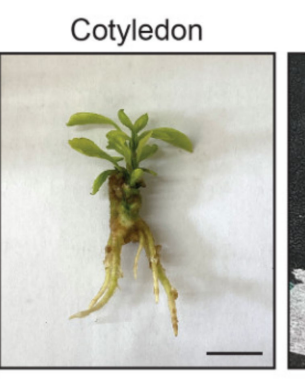

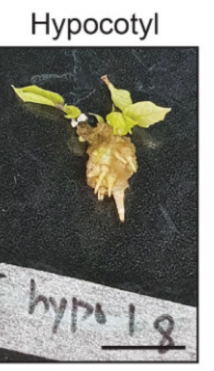

Figure 2. Comparison of organogenesis efficiencies among three explant types in Capsicum annuum L. 'Dempsey'. (A) The graph of shooting rates of three explant types; first leaves, cotyledons and hypocotyls. (B) The images of shoot buds from the first leaf, a cotyledon and a hypocotyl. scale bars = $1 \mathrm{~mm}$. (C) The graph of rooting rates of shoots obtained from three explant types; first leaves, cotyledons and hypocotyls. (D) The images of shoots with protruded roots from three explant types. scale bars $=1 \mathrm{~cm}$, the dots in the graphs indicate the number of biological replicates. This study used a total of 234 first leaves, 285 cotyledons and 67 hypocotyls from 69 Dempsey plants. ns, non-significant difference; ${ }^{*}, p<0.05 ;{ }^{* *}, p<0.01$ based on analysis of variance (ANOVA).

\subsection{Phenotypic and Cytogenetic Analysis of 'Dempsey' Regenerants and Their Progenies}

The successfully acclimated seven 'Dempsey' regenerants (R0) naturally generated mature fruits (Figure 3A and Table 2). Seed yield and fertility are crucial indicators of agronomic and reproductive performance. To investigate the fertility of 'Dempsey' regenerants, we harvested all ten mature 'Dempsey' fruit from all seven regenerants (R0) and observed the fruit size (with a typical length of $6.5 \mathrm{~cm}$ ), and their seeds (Figure 3B,C and Table 2). Mature fruit of the regenerants had no phenotypic defects and an average number of seeds, compared to the 'Dempsey' control (Figure 3D and Table 2). To further investigate the viability of offspring of R0, we compared phenotypes and cytogenetic features with chromosomal numbers between the 'Dempsey' control plants and eleven progenies of regenerants (R1). The R1 plants were grown without any obstacles and showed normal phenotype similar to that of the 'Dempsey' control plants under the same growth conditions (Figure 3E,G and Table 2). We also verified the chromosome numbers of the root tips from the soil-grown eleven R1 plants and twelve 'Dempsey' controls, using DAPI staining to analyse the cytogenetic features. The 24 DAPI-stained chromosomes of R1 plants were clearly observed, similar to the 'Dempsey' control plants $(2 \mathrm{n}=24)$ (Figures $3 \mathrm{~F}, \mathrm{H}$ and $\mathrm{S1}$ ). Moreover, we performed fluorescence in situ hybridisation (FISH) using three molecular cytogenetic markers, $5 \mathrm{~S}$ rDNA, $45 \mathrm{~S}$ rDNA and telomeric repeats, 
to perform the inter- or intrachromosomal comparison. The FISH analyses exhibited consistent cytogenetic positions at the chromosomes of both wild type Dempsey specimens and their regenerants (Figure S1). We further observed that 'Dempsey' R2 progenies were properly germinated in a wet filter and showed normal nine-day-old seedlings (Figure S2). Phenotypic and cytogenetic analyses of the regenerants and their progenies confirmed that the 'Dempsey' regeneration method had no adverse effect on pepper growth, development and chromosomal number, thus highlighting the value of the proposed method for bell pepper improvement.
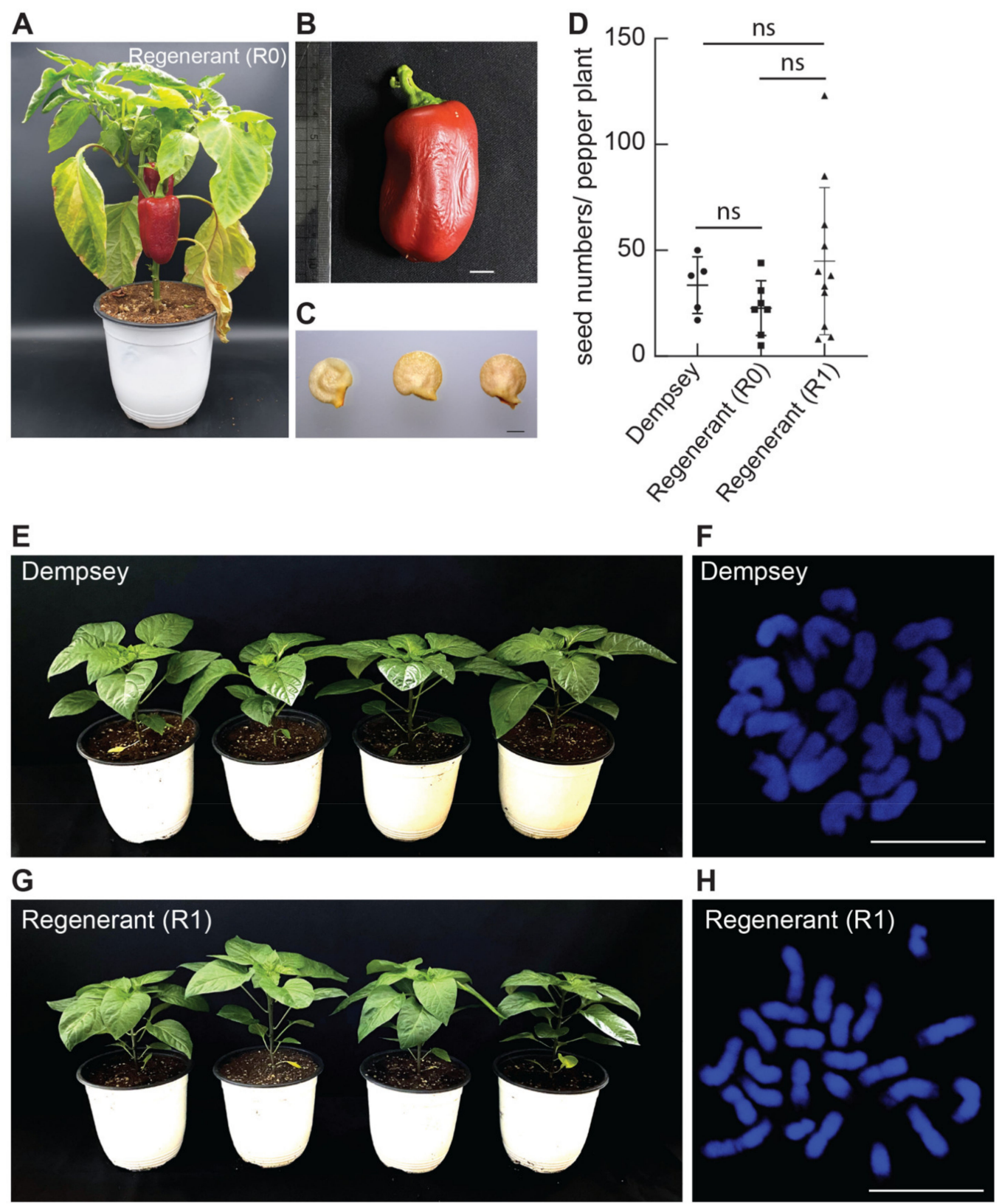

Figure 3. Phenotypic and cytogenetic analyses of 'Dempsey' regenerants (R0) and their progenies (R1). (A) Representative image of 'Dempsey' regenerant (R0) with two mature fruit in $15 \mathrm{~cm}$ diameter of pot. (B) Harvested fruit of the regenerant, scale bar $=1 \mathrm{~cm}$. (C) Harvested seeds from the fruit, scale bar $=1 \mathrm{~mm}$. (D) Harvested seeds from five 'Dempsey' plants, seven Regenerants (R0), and eleven Regenerants (R1); all plants produced comparable seed numbers, ns: non-significant difference. (E,G) 8-week-old, soil-grown 'Dempsey' plants (E) or Regenerant (R1) plants (G) in 15 cm diameter of pot. $(\mathbf{F}, \mathbf{H})$ Representative images of cytogenetic analysis of 'Dempsey' (F) or Regenerants (R1) (H). Both DAPI-stained images showed unaltered chromosome numbers $(2 \mathrm{n}=24)$, scale bar $=10 \mu \mathrm{m}$. 
Table 2. Summary of 'Dempsey' pepper fruit and seed numbers, including those of its regenerants and their progenies.

\begin{tabular}{|c|c|c|c|c|c|c|c|c|c|c|c|}
\hline $\begin{array}{c}\text { ‘Dempsey' } \\
\text { (WT) }\end{array}$ & $\begin{array}{l}\text { Number } \\
\text { of Fruit }\end{array}$ & $\begin{array}{l}\text { Number } \\
\text { of Seed }\end{array}$ & $\begin{array}{l}\text { Total } \\
\text { Seeds }\end{array}$ & $\begin{array}{l}\text { Regenerant } \\
\text { (R0) }\end{array}$ & $\begin{array}{l}\text { Number } \\
\text { of Fruit }\end{array}$ & $\begin{array}{l}\text { Number } \\
\text { of Seed }\end{array}$ & $\begin{array}{l}\text { Total } \\
\text { Seeds }\end{array}$ & $\begin{array}{l}\text { Regenerant } \\
\text { (R1) }\end{array}$ & $\begin{array}{l}\text { Number } \\
\text { of Fruit }\end{array}$ & $\begin{array}{l}\text { Number } \\
\text { of Seed }\end{array}$ & $\begin{array}{l}\text { Total } \\
\text { Seeds }\end{array}$ \\
\hline$\# 1$ & 1 & 50 & 50 & \multirow{3}{*}{$\# 1$} & 1 & 23 & \multirow{3}{*}{44} & $\# 1$ & 1 & 123 & 123 \\
\hline$\# 2$ & 1 & 40 & 40 & & 2 & 19 & & $\# 2$ & 1 & 85 & 85 \\
\hline$\# 3$ & 1 & 38 & 38 & & 3 & 2 & & \multirow{2}{*}{ \#3 } & 1 & 32 & \multirow{2}{*}{62} \\
\hline$\# 4$ & 1 & 23 & 23 & \multirow{2}{*}{$\# 2$} & 1 & 19 & \multirow{2}{*}{31} & & 2 & 30 & \\
\hline \multirow[t]{10}{*}{$\# 5$} & 1 & 17 & 17 & & 2 & 12 & & \multirow{3}{*}{$\# 4$} & 1 & 10 & \multirow{3}{*}{52} \\
\hline & & & & $\# 3$ & 1 & 25 & 25 & & 2 & 13 & \\
\hline & & & & $\# 4$ & 1 & 22 & 22 & & 3 & 29 & \\
\hline & & & & $\# 5$ & 1 & 22 & 22 & $\# 5$ & 1 & 40 & 40 \\
\hline & & & & $\# 6$ & 1 & 10 & 10 & $\# 6$ & 1 & 38 & 38 \\
\hline & & & & $\# 7$ & 1 & 5 & 5 & $\# 7$ & 1 & 33 & 33 \\
\hline & & & & & & & & $\# 8$ & 1 & 30 & 30 \\
\hline & & & & & & & & \#9 & 1 & 14 & 14 \\
\hline & & & & & & & & $\# 10$ & 1 & 9 & 9 \\
\hline & & & & & & & & $\# 11$ & 1 & 8 & 8 \\
\hline
\end{tabular}

\section{Discussion}

Here, we report that the first leaves are the most appropriate explant type for the regeneration of 'Dempsey'. The shooting rate of the first leaves, average $69.8 \%$ exceeded that of hypocotyls and cotyledons, and even reached $100 \%$. The first leaves exhibited 2.7 or 3.5 times higher shooting rate than cotyledons or hypocotyls, respectively. In seven of eight experiments, the first leaves show higher shooting and rooting efficiency than other explants. It is a novel feature of 'Dempsey' regeneration compared to 'Jupiter', one of breeding parents of 'Dempsey', which was regenerated by cotyledonary explants [28].

Previous studies showed that pepper cultivars exhibited different regeneration efficiencies depending on their genotypes, tissues and conditions [29,30,38-42]. Bell pepper cultivars from South Tunisia and Valencia exhibited that hypocotyl explants had a better regeneration rate than cotyledonary explants [30]. True leaves were primarily used for transient assays with Agrobacterium-infiltration or protoplast-based transformation in many other crops [43-46]. However, there is no clear evidence of the first leaves as an explant type in bell pepper regeneration. Recently, we reported that true leaves of 'Dempsey' successfully produced sustainable callus line to provide continuous pepper protoplasts and efficiently edited by CRISPR tools [31,32]. It suggested that there are unique characteristics of the pepper explant types in the regeneration conditions.

Abnormal morphology of organogenesis including leaves and stems were reported the cause of obstacle in pepper regeneration [47,48]. It was reported that 'Jupiter' and 'Pimiento Perfection' required not Zeatin but 24 epi-brassinolide for normal shoot growth [28]. However, 'Dempsey' shoot buds were successfully elongated with Zeatin and $\mathrm{GA}_{3}$ contained SEM. Because the regenerated shoots had no defects in bud formation, shoot growth and leaf differentiation, the shoot induction and elongation conditions were already proficient in 'Dempsey' (Table 1).

Even though the highest shooting rate was reached $100 \%$, the subsequent rooting rate was drastically decreased to $13.4 \%$. The transition from shoot to root in our method is the next step in improving the regeneration efficiency. Several reports have suggested that activated charcoal in pinus or phloroglucinol in apples improved and strengthened the rooting steps of tissue culture $[49,50]$. These additional substances might be considered as root-promoting agents for 'Dempsey' regeneration.

As a proven genome-editable bell pepper, Capsicum annuum L. 'Dempsey' is an excellent genetic resource for precise genome editing [31]. Based on the genetic background of breeding protocols and previous pepper tissue culture studies [28,37-40], we successfully established the 'Dempsey' regeneration method and obtained mature whole plants 
with healthy fruit and fertile seeds. Previous reports found that the seed yield of pepper regenerants showed genotype-dependent differences [41,51], and somaclonal variations of tissue-cultured plants caused phenotypic and cytogenetic problems in the regenerants and their offspring [52-54]. Therefore, chromosomal alteration is critical for plant biotechnology and crop molecular breeding. We confirmed that regenerants (R0) and their offspring (R1) plants had no altered phenotype or reproductivity without any chromosomal number change.

\section{Conclusions}

We established a reliable regeneration protocol for the precise molecular breeding of the 'Dempsey' bell pepper cultivar. Based on our results, the first leaves were the most suitable explant for bell pepper regeneration. The 'Dempsey' regenerants and their progeny produced healthy peppers and fertile seeds without phenotype alterations. Moreover, the offspring of the regenerants had the same chromosome numbers $(2 n=24)$ and had no apparent chromosomal abnormalities. Therefore, our reliable regeneration method provides a means to improve 'Dempsey' bell peppers when coupled with genome editing tools such as CRISPR systems.

Supplementary Materials: The following are available online at https://www.mdpi.com/article/ 10.3390/horticulturae7090317/s1, Figure S1: Cytogenetic analysis and karyogram of chromosomes from the 'Dempsey' WT and regenerant (R1), Figure S2: Germination analysis of the 'Dempsey' regenerant (R2), Table S1: The summary of regeneration with three types of 'Dempsey' explants from eight biological replicates.

Author Contributions: Conceptualisation, H.K.; methodology, K.-H.W., S.-i.P., H.H.K., H.K.; investigation, K.-H.W., S.-i.P., J.C.; resources, H.H.K., B.-C.K.; data curation, K.-H.W., S.-i.P.; writing—original draft preparation, K.-H.W., H.K.; writing-review and editing, K.-H.W., S.-i.P., H.K.; supervision, H.K.; project administration, H.K.; funding acquisition, H.K. All authors have read and agreed to the published version of the manuscript.

Funding: This research was supported by grants from the New Breeding Technologies Development Program (Project No. PJ01477602), Rural Development Administration (RDA), and the Basic Science Research Program (NRF-2018R1A2B6006233) of the National Research Foundation of Korea to H.K. This study was partly supported by the Korea Basic Science Institute (KBSI) National Research Facilities \& Equipment Center (NFEC) grant founded by the Korea government (Ministry of Education) (2019R1A6C1010006).

Institutional Review Board Statement: Not applicable.

Informed Consent Statement: Not applicable.

Data Availability Statement: All data supporting reported results can be found in the article.

Acknowledgments: We are grateful to the Vegetable Breeding Research Center in Korea for sharing 'Dempsey'.

Conflicts of Interest: The funders had no role in the design of the study; in the collection, analyses, or interpretation of data; in the writing of the manuscript, or in the decision to publish the results. The authors declare no conflict of interest.

\section{References}

1. Pickersgill, B. Genetic resources and breeding of Capsicum spp. Euphytica 1997, 96, 129-133. [CrossRef]

2. Kang, J.H.; Yang, H.B.; Jeong, H.S.; Choe, P.; Kwon, J.K.; Kang, B.C. Single nucleotide polymorphism marker discovery from transcriptome sequencing for marker-assisted backcrossing in Capsicum. Korean J. Hortic. Sci. Technol. 2014, 32, 535-543. [CrossRef]

3. Qin, C.; Yu, C.; Shen, Y.; Fang, X.; Chen, L.; Min, J.; Cheng, J.; Zhao, S.; Xu, M.; Luo, Y.; et al. Whole-genome sequencing of cultivated and wild peppers provides insights into Capsicum domestication and specialization. Proc. Natl. Acad. Sci. USA 2014, 111, 5135-5140. [CrossRef] [PubMed]

4. Han, K.; Jang, S.; Lee, J.-H.; Lee, D.-G.; Kwon, J.-K.; Kang, B.-C. A MYB transcription factor is a candidate to control pungency in Capsicum annuum. Theor. Appl. Genet. 2019, 132, 1235-1246. [CrossRef] [PubMed] 
5. Blum, E.; Mazourek, M.; O'Connell, M.; Curry, J.; Thorup, T.; Liu, K.; Jahn, M.; Paran, I. Molecular mapping of capsaicinoid biosynthesis genes and quantitative trait loci analysis for capsaicinoid content in Capsicum. Theor. Appl. Genet. 2003, $108,79-86$. [CrossRef] [PubMed]

6. Lane, R.P.; McCarter, S.M.; Kuhn, C.W.; Deom, C.M. “Dempsey”, a virus- and bacterial spot-resistant bell pepper. HortScience 1997, 32, 333-334. [CrossRef]

7. Hill, T.A.; Ashrafi, H.; Reyes-Chin-Wo, S.; Yao, J.; Stoffel, K.; Truco, M.-J.; Kozik, A.; Michelmore, R.W.; Van Deynze, A. Characterization of Capsicum annuum genetic diversity and population structure based on parallel polymorphism discovery with a 30K unigene Pepper GeneChip. PLoS ONE 2013, 8, e56200. [CrossRef]

8. Han, K.; Jeong, H.-J.; Yang, H.-B.; Kang, S.-M.; Kwon, J.-K.; Kim, S.; Choi, D.; Kang, B.-C. An ultra-high-density bin map facilitates high-throughput QTL mapping of horticultural traits in pepper (Capsicum annuum). DNA Res. 2016, 23, 81-91. [CrossRef]

9. Han, K.; Lee, H.-Y.; Ro, N.-Y.; Hur, O.-S.; Lee, J.-H.; Kwon, J.-K.; Kang, B.-C. QTL mapping and GWAS reveal candidate genes controlling capsaicinoid content in Capsicum. Plant Biotechnol. J. 2018, 16, 1546-1558. [CrossRef]

10. Wang, Y.; Cheng, X.; Shan, Q.; Zhang, Y.; Liu, J.; Gao, C.; Qiu, J.-L. Simultaneous editing of three homoeoalleles in hexaploid bread wheat confers heritable resistance to powdery mildew. Nat. Biotechnol. 2014, 32, 947-951. [CrossRef]

11. Woo, J.W.; Kim, J.; Kwon, S.I.; Corvalan, C.; Cho, S.W.; Kim, H.; Kim, S.-G.; Kim, S.-T.; Choe, S.; Kim, J.-S. DNA-free genome editing in plants with preassembled CRISPR-Cas9 ribonucleoproteins. Nat. Biotechnol. 2015, 33, 1162-1164. [CrossRef]

12. Kim, H.; Kim, S.T.; Ryu, J.; Kang, B.C.; Kim, J.S.; Kim, S.G. CRISPR/Cpf1-mediated DNA-free plant genome editing. Nat. Commun. 2017, 8, 1-7. [CrossRef] [PubMed]

13. Mohanta, T.K.; Bashir, T.; Hashem, A.; Abd Allah, E.F.; Bae, H. Genome editing tools in plants. Genes 2017, 19, 399. [CrossRef]

14. Zhang, D.; Zhang, Z.; Unver, T.; Zhang, B. CRISPR/Cas: A powerful tool for gene function study and crop improvement. J. Adv. Res. 2020, 21, 207-221. [CrossRef]

15. Barton, K.A.; Binns, A.N.; Matzke, A.J.; Chilton, M.D. Regeneration of intact tobacco plants containing full length copies of genetically engineered T-DNA, and transmission of T-DNA to R1 progeny. Cell 1983, 32, 1033-1043. [CrossRef]

16. Fillatti, J.J.; Kiser, J.; Rose, R.; Comai, L. Efficient transfer of a glyphosate tolerance gene into tomato using a binary Agrobacterium tumefaciens Vector. Bio/Technology 1987, 5, 726-730. [CrossRef]

17. Han, E.H.; Goo, Y.M.; Lee, M.K.; Lee, S.W. An efficient transformation method for a potato (Solanum tuberosum L. var. Atlantic). J. Plant Biotechnol. 2015, 42, 77-82. [CrossRef]

18. Muktadir, M.A.; Habib, M.A.; Khaleque Mian, M.A.; Yousuf Akhond, M.A. Regeneration efficiency based on genotype, culture condition and growth regulators of eggplant (Solanum melongena L.). Agric. Nat. Resour. 2016, 50, 38-42. [CrossRef]

19. Lee, Y.H.; Kim, H.S.; Kim, J.Y.; Jung, M.; Park, Y.S.; Lee, J.S.; Choi, S.H.; Her, N.H.; Lee, J.H.; Hyung, N.I.; et al. A new selection method for pepper transformation: Callus-mediated shoot formation. Plant Cell Rep. 2004, 23, 50-58. [CrossRef]

20. Moon, K.K.; Soh, H.; Kim, K.M.; Young, S.K.; Im, K. Stable production of transgenic pepper plants mediated by Agrobacterium tumefaciens. HortScience 2007, 42, 1425-1430. [CrossRef]

21. Maligeppagol, M.; Manjula, R.; Navale, P.M.; Prasad Babu, K.; Kumbar, B.M.; Laxman, R.H. Genetic transformation of chilli (Capsicum annuum L.) with Dreb1A transcription factor known to impart drought tolerance. Indian J. Biotechnol. 2016, 15, 17-24.

22. Mahto, B.K.; Sharma, P.; Rajam, M.V.; Reddy, P.M.; Dhar-Ray, S. An efficient method for Agrobacterium-mediated genetic transformation of chilli pepper (Capsicum annuum L.). Indian J. Plant Physiol. 2018, 23, 573-581. [CrossRef]

23. Bagga, S.; Lucero, Y.; Apodaca, K.; Rajapakse, W.; Lujan, P.; Ortega, J.L.; Sengupta-Gopalan, C. Chile (Capsicum annuum) plants transformed with the RB gene from Solanum bulbocastanum are resistant to Phytophthora capsici. PLoS ONE 2019, 14, e0223213. [CrossRef] [PubMed]

24. Ahmad, N.; Siddique, I.; Anis, M. Improved plant regeneration in Capsicum annuum L. from nodal segments. Biol. Plant. 2006, 50, 701-704. [CrossRef]

25. Kumar, R.V.; Sharma, V.K.; Chattopadhyay, B.; Chakraborty, S. An improved plant regeneration and Agrobacterium-Mediated transformation of red pepper (Capsicum annuum L.). Physiol. Mol. Biol. Plants 2012, 18, 357-364. [CrossRef]

26. Mahto, B.K.; Singh, A.; Pareek, M.; Rajam, M.V.; Dhar-Ray, S.; Reddy, P.M. Host-induced silencing of the Colletotrichum gloeosporioides conidial morphology 1 gene (CgCOM1) confers resistance against Anthracnose disease in chilli and tomato. Plant Mol. Biol. 2020, 104, 381-395. [CrossRef]

27. Prakash, A.H.; Sankara Rao, K.; Kumar, M.U. Plant regeneration from protoplasts of Capsicum annuum L. cv. California Wonder. J. Biosci. 1997, 22, 339-344. [CrossRef]

28. Franck-Duchenne, M.; Wang, Y.; Ben Tahar, S.; Beachy, R.N. In vitro stem elongation of sweet pepper in media containing 24-epi-brassinolide. Plant Cell Tissue Organ Cult. 1998, 53, 79-84. [CrossRef]

29. Dabauza, M.; Peña, L. High Efficiency Organogenesis in Sweet Pepper (Capsicum annuum L.) tissues from different seedling explants. Plant Growth Regul. 2001, 33, 221-229. [CrossRef]

30. Gammoudi, N.; Pedro, T.S.; Ferchichi, A.; Gisbert, C. Improvement of regeneration in pepper: A recalcitrant species. In Vitro Cell. Dev. Biol. Plant 2018, 54, 145-153. [CrossRef]

31. Kim, H.; Choi, J.; Won, K.-H. A stable DNA-free screening system for CRISPR/RNPs-mediated gene editing in hot and sweet cultivars of Capsicum annuum. BMC Plant Biol. 2020, 20, 449. [CrossRef] [PubMed]

32. Park, S.-I.; Kim, H.-B.; Jeon, H.-J.; Kim, H. Agrobacterium-mediated Capsicum annuum gene editing in two cultivars, hot pepper CM334 and bell pepper Dempsey. Int. J. Mol. Sci. 2021, 22, 3921. [CrossRef] [PubMed] 
33. Kato, A.; Lamb, J.C.; Birchler, J.A. Chromosome painting using repetitive DNA sequences as probes for somatic chromosome identification in maize. Proc. Natl. Acad. Sci. USA 2004, 101, 13554-13559. [CrossRef]

34. Waminal, N.E.; Pellerin, R.J.; Kim, N.S.; Jayakodi, M.; Park, J.Y.; Yang, T.J.; Kim, H.H. Rapid and efficient FISH using pre-labeled oligomer probes. Sci. Rep. 2018, 8, 8224. [CrossRef]

35. Zhou, H.C.; Waminal, N.E.; Kim, H.H. In silico mining and FISH mapping of a chromosome-specific satellite DNA in Capsicum annuum L. Genes Genom. 2019, 41, 1001-1006. [CrossRef]

36. Abd El-Twab, M.H.; Kondo, K. FISH physical mapping of 5S, 45S and Arabidopsis-type telomere sequence repeats in Chrysanthemum zawadskii showing intra-chromosomal variation and complexity in nature. Chromosome Bot. 2006, 1, 1-5. [CrossRef]

37. Kim, H.; Lim, J. Leaf-induced callus formation in two cultivars: Hot pepper "CM334" and bell pepper "Dempsey". Plant Signal. Behav. 2019, 14, 1604016. [CrossRef]

38. Verma, S.; Dhiman, K.; Srivastava, D.K. Efficient in vitro regeneration from cotyledon explants in bell pepper (Capsicum annuum L. cv. California Wonder). Int. J. Adv. Biotechnol. Res. 2013, 4, 391-396.

39. Akther, S.; Banu, T.; Khan, S.; Akter, S.; Habib, A.; Islam, M.; Goswami, B.; Sarkar, B. Micropropagation of two varieties of bell pepper (Capsicum annuum L.). Plant Tissue Cult. Biotechnol. 2020, 30, 267-275. [CrossRef]

40. Kothari, S.L.; Joshi, A.; Kachhwaha, S.; Ochoa-Alejo, N. Chilli peppers-A review on tissue culture and transgenesis. Biotechnol. Adv. 2010, 28, 35-48. [CrossRef]

41. Valadez-Bustos, M.G.; Aguado-Santacruz, G.A.; Carrillo-Castañeda, G.; Aguilar-Rincón, V.H.; Espitia-Rangel, E.; MontesHernández, S.; Robledo-Paz, A. In vitro propagation and agronomic performance of regenerated chili pepper (Capsicum spp.) plants from commercially important genotypes. In Vitro Cell. Dev. Biol. Plant 2009, 45, 650. [CrossRef]

42. İ̇gü, T.; İlbi, H.; Mendi, Y.Y. Optimization of plant regeneration in different Pepper (Capsicum annuum L.). Turk. J. Agric. Food Sci. Technol. 2020, 8, 471-477. [CrossRef]

43. Jia, H.; Liao, M.; Verbelen, J.P.; Vissenberg, K. Direct creation of marker-free tobacco plants from agroinfiltrated leaf discs. Plant Cell Rep. 2007, 26, 1961-1965. [CrossRef]

44. Zottini, M.; Barizza, E.; Costa, A.; Formentin, E.; Ruberti, C.; Carimi, F.; Lo Schiavo, F. Agroinfiltration of grapevine leaves for fast transient assays of gene expression and for long-term production of stable transformed cells. Plant Cell Rep. 2008, 27, 845-853. [CrossRef]

45. Faizal, A.; Geelen, D. Agroinfiltration of intact leaves as a method for the transient and stable transformation of saponin producing Maesa lanceolata. Plant Cell Rep. 2012, 31, 1517-1526. [CrossRef] [PubMed]

46. Yamamoto, T.; Hoshikawa, K.; Ezura, K.; Okazawa, R.; Fujita, S.; Takaoka, M.; Mason, H.S.; Ezura, H.; Miura, K. Improvement of the transient expression system for production of recombinant proteins in plants. Sci. Rep. 2018, 8, 4755. [CrossRef] [PubMed]

47. Ochoa-Alejo, N.; Ramirez-Malagon, R. In vitro chili pepper biotechnology. In Vitro Cell. Dev. Biol. Plant 2001, 37, 701-729, doiorg/101007/s11627. [CrossRef]

48. Mezghani, N.; Jemmali, A.; Elloumi, N.; Gargouri-Bouzid, R.; Kintzios, S. Morpho-histological study on shoot bud regeneration in cotyledon cultures of pepper (Capsicum annuum). Biologia 2007, 62, 704-710. [CrossRef]

49. Zimmerman, R.H. Rooting apple cultivars in vitro: Interactions among light, temperature, phloroglucinol and auxin. Plant Cell. Tissue Organ Cult. 1984, 3, 301-311. [CrossRef]

50. Dumas, E.; Monteuuis, O. In vitro rooting of micropropagated shoots from juvenile and mature Pinus pinaster explants: Influence of activated charcoal. Plant Cell. Tissue Organ Cult. 1995, 40, 231-235. [CrossRef]

51. Grozeva, S.; Todorova, V. In vitro regeneration in pepper (Capsicum annuum L.) and characterization of plant-regenerants. Electron. J. Biol. 2015, 11, 17-22.

52. Barwale, U.B.; Widholm, J.M. Somaclonal variation in plants regenerated from cultures of soybean. Plant Cell Rep. 1987, 6, 365-368. [CrossRef] [PubMed]

53. Lewis-Smith, A.C.; Chamberlain, M.; Smith, S.M. Genetic and chromosomal variation in Petunia hybrida plants regenerated from protoplast and callus cultures. Biol. Plant. 1990, 32, 247-255. [CrossRef]

54. Ezura, H.; Amagai, H.; Yoshioka, K.; Oosawa, K. Efficient production of tetraploid melon (Cucumis melo L.) by somatic embryogenesis. Jpn. J. Breed. 1992, 42, 137-144. [CrossRef] 